\title{
Вплив анестезіі та післяопераційної аналгезіі на ранню мобілізацію пацієнтів після артропластики кульшового суглоба
}

\author{
В. І. Коломаченко \\ Харківська медична академія післядипломної освіти

\section{Impact of anesthesia and postoperative analgesia on early mobilization of patients after the hip joint arthroplasty V. I. Kolomachenko}

Kharkiv Medical Academy of Postgraduate Education

\section{Реферат}

Мета. Аналіз впливу анестезії та післяопераційної (ПО) аналгезії на здатність пацієнтів рухатись після артропластики кульшового суглоба (КС).

Матеріали і методи. У 150 паціентів оцінювали дистанцію, яку вони проходили за 6 хв, протягом трьох діб після артропластики КС в залежності від методики інтраопераційної (ІО) анестезії та ПО аналгезії.

Результати. Пацієнти, яких оперували з використанням паравертебральної блокади в поєднанні з каудальною епідуральною анестезією, демонстрували кращі результати 6-хвилинного тесту в порівнянні з паціентами, яких оперували під загальною анестезією, в умовах провідникової анестезії та під спінальною анестезією. В післяопераційному періоді пацієнти, які отримували тривалу паравертебральну аналгезію, краще долали відстань за 6 хв порівняно 3 пацієнтами, яким застосовували системне введення опіоїдів та епідуральну аналгезію.

Висновки. Паравертебральна блокада сприяє ранньому фізичному відновленню пацієнтів після артропластики КС.

Ключові слова: хірургія кульшового суглоба; анестезія; аналгезія; здатність рухатись.

Abstract

Objective. Analysis of anesthesia and postoperative analgesia, concerning capacity of patients to pass after the hip joint arthroplasty.

Materials and methods. In 150 patients the distance was estimated, which they passed for 6 min. The investigation was done during 3 days after arthroplasty of the hip joint, depending on method of intraoperative anesthesia and postoperative analgesia. Results. The patients, who were operated on, using paravertebral blockade in combination with caudal epidural anesthesia, have shown better results of the 6-minute test, comparing with patients, who were operated under general anesthesia, with conduction and spinal anesthesia. In postoperative period the patients, who obtained durable paravertebral analgesia, better covered the distance for $6 \mathrm{~min}$, comparing with patients, to whom systemic injections of opioids and epidural analgesia were applied.

Conclusion. Paravertebral blockade promotes early physical restoration in patients after arthroplasty of the hip joint.

Keywords: surgery of the hip joint; anesthesia; analgesia; capacity to pass.

У разі ранньої мобілізації хворих після артропластики КС знижується ризик виникнення венозних тромбоемболічних ускладнень та покращується якість життя [1]. Традиційно знеболення після таких оперативних втручань проводиться в мультимодальному режимі з використанням наркотичних та ненаркотичних аналгетиків, яким притаманні небажані побічні ефекти, що призводять до зниження загальної активності пацієнтів [2]. Альтернативою є застосування регіонарних методів знеболення у вигляді одноразової або подовженої ін'єкції 3 використанням катетерних методик, введенням місцевого анестетика до відповідних нервових структур [3]. Методи регіонарної періопераційної анестезії та аналгезіі можуть обмежувати фізичну активність пацієнтів через руховий блок кінцівок [4].

Мета дослідження: аналіз впливу IO анестезії та ПО аналгезії на здатність пацієнтів рухатись після артропластики КС.

\section{Матеріали і методи дослідження}

Дослідження охоплює 150 пацієнтів, яким у 2014 2016 рр. у Харківській обласній клінічній травматологічній лікарні у плановому порядку виконано первинну артропластику КС (ASA II-III). Жінок було 94, чоловіків - 56 віком від 29 до 84 років. Середній вік - $(63,3 \pm 12,5)$ року. Інформована згода отримана від усіх пацієнтів до проведення дослідження. Пацієнтів випадковим чином розподілили на шість груп (по 25 у кожній) в залежності від IO анестезіі та ПО аналгезіі. У групі І виконували спінальну анестезію на рівні L3-4 голкою G26 парамедіанним доступом у положенні на здоровому боці з уведенням 12 мг (2,4 мл) 0,5\% розчину бупівакаїну; після операції опіоїди вводили внутрішньом'язово. У групі II після виконання аналогічної спінальної анестезії проводили катетеризацію паравертебрального простору із застосуванням набору Perifix 401 (B. Braun, Німеччина) на рівні L3 на оперованому боці з уведенням 20 мл 1\% розчину лідокаїну. 


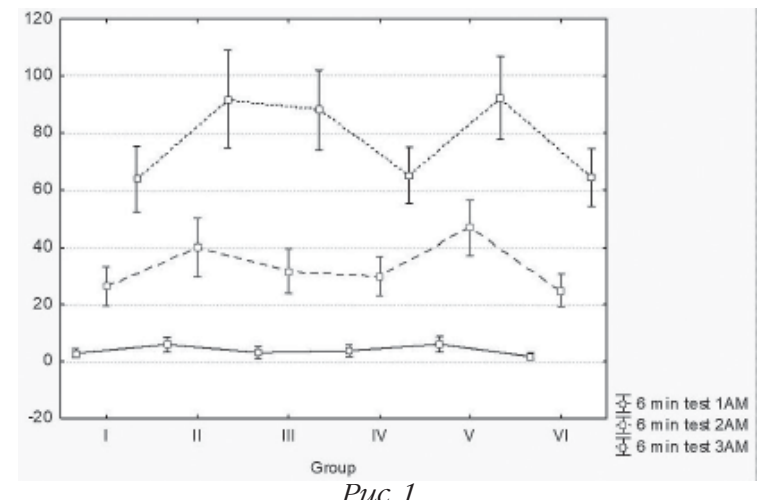

Відстань, подолана пацієнтами за 6 хв, на ранок 1-иої, 2-гої та 3-тьої ооби після операції.

Після операції в катетер вводили 0,25\% розчин бупівакаїну в першу добу в темпі 3 мл/год, в наступні 3 - 4 доби по 10 мл тричі за добу. У групі III виконували спінальноепідуральну анестезію на рівні L3, а оперували під спінальною анестезією. Після операції в епідуральний катетер вводили 0,125\% розчин бупівакаїну в першу добу в темпі 3 мл/год, в наступні 3 - 4 доби - по 10 мл тричі за добу. У групі IV виконували одноразову блокаду поперекового сплетіння заднім доступом за Capdevila в комбінації з блокадою сідничного нерва за Labat-Moore 1\% розчином лідокаїну в дозі 800 мг з додаванням адреналіну 1:200000 та дексаметазону 4 мг. Після операції опіоїди вводили внутрішньом'язово. У групі V виконували блокаду поперекового сплетіння заднім доступом за Capdevila 3 наступною катетеризацією псоас-компартменту в комбінації з каудальною блокадою з використанням 20 мл 0,75\% розчину ропівакаїну. Одразу після операції в катетер вводили 0,25\% розчин бупівакаїну в першу добу в темпі 3 мл/год, в наступні 3 - 4 доби - по 10 мл тричі за добу. В групі VI проводили загальну анестезію пропофолом по цільовій концентрації з фентанілом та атракуріумом в загальноприйнятих дозах з інтубацією трахеї та штучною вентиляцією легень. Після операції опіоїди вводили внутрішньом'язово. У всіх пацієнтів як компоненти мультимодальної аналгезії застосовували парацетамол, нестероїдний протизапальний засіб, інфільтрацію шкіри та параартикулярних тканин місцевим анестетиком низької концентрації. Статистично значущої різниці між групами за демографічними показниками не виявлено.

Хворих спонукали до ранньої фізичної активності, дозволяючи ходити з ортопедичними опорними ходунками або на милицях з 70\% навантаженням на оперовану кінцівку з першої доби після операції. Оцінювали відстань, яку пацієнт міг пройти за 6 хв (6-хвилинний тест) вранці та ввечері 1-шої, 2-гої та 3-тьої доби після операціiі.

Для статистичного аналізу використовували статистичний пакет Portable Statistica 8 (SPSS, v. 11.0 для Windows; SPSS Inc., Chicago, Illinois, USA). Для аналізу відмінностей між групами використані непарні t-тести, за рівень достовірності різниці вважали $\mathrm{p}<0,05$. Результати подані у вигляді: середнє значення (M) \pm стандартне відхилення (б). Графіки будували для середніх значень параметрів у групах із встановленням довірчих інтервалів на рівні 95\%.

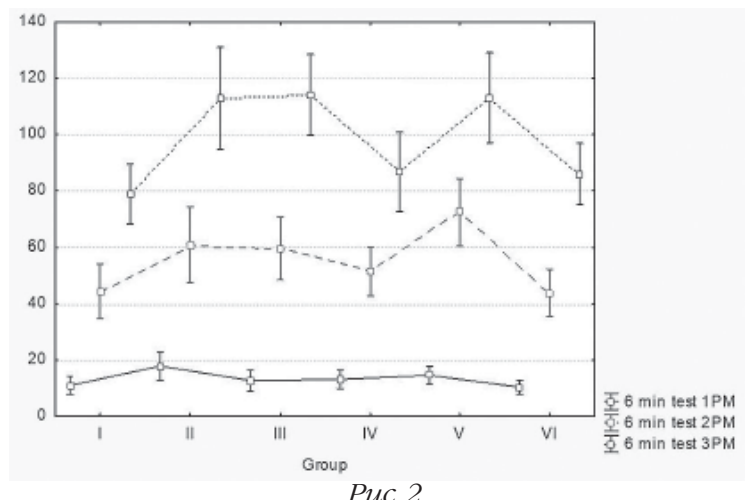

Відстань, подолана пащієнтами за 6 хв, на вечір 1-иої, 2-гої та 3-тьої ооби після операції.

\section{Результати}

У 1-шу добу після операції зранку відстань, яку долали пацієнти за 6 хв, становила: у групі I - $(2,9 \pm 0,8)$ м, у групі II - $(6,0 \pm 1,3)$ м, у групі III - $(3,1 \pm 1,0)$ м, у групі IV $(3,8 \pm 0,9)$ м, у групі $\mathrm{V}-(6,1 \pm 1,3)$ м, у групі VI - $(1,8 \pm 0,6)$ м. На ранок 2-гої доби після операції показники 6-хвилинного тесту були такі: у групі I - $(26,3 \pm 3,3)$ м, у групі II - (39,9 4 4,9) м, у групі III - $(31,8 \pm 3,8)$ м, у групі IV - (30,1 $\pm 3,3)$ м, у групі V - $(46,8 \pm 4,7)$ м, у групі VI $-(24,3 \pm 2,8)$ м. На ранок 3-тьої доби після операції пацієнти групи I за 6 хв змогли пройти $(63,8 \pm 5,6)$ м, групи II - $(91,9 \pm 8,3)$ м, групи III - $(88,1 \pm 6,8)$ м, групи IV - $(65,2 \pm 4,7)$ м, групи V - $(92,4 \pm 7,1)$ м, групи VI - $(63,5 \pm 5,1)$ м (рис. 1$)$.

Відстань, подолана за 6 хв пацієнтами групи I, була статистично значно нижчою, ніж відстань, подола-

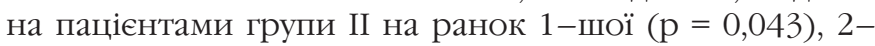
гої ( $\mathrm{p}=0,027)$ та 3-тьої ( $\mathrm{p}=0,008)$ доби після операції, ніж відстань, подолана пацієнтами групи $\mathrm{V}$ на ранок 1шої ( $=0,042), 2$-гої $(\mathrm{p}<0,001)$ та 3-тьої $(\mathrm{p}=0,003)$ доби після операції, та відстань, подолана пацієнтами групи III на ранок 3-тьої $(\mathrm{p}=0,008)$ доби після операції. За 6 хв пацієнти групи VI проходили статистично значно меншу відстань, ніж пацієнти групи II на ранок 1-шої (р = 0,005), 2-гої $(\mathrm{p}=0,009)$ та 3-тьої ( $\mathrm{p}=0,006)$ доби після операції, ніж пацієнти групи V на ранок 1-шої (p = 0,005), 2-гої $(\mathrm{p}<0,001)$ та 3-тьої $(\mathrm{p}=0,002)$ доби після операції, та пацієнти групи III на ранок 3-тьої $(\mathrm{p}=0,006)$ доби після операції.

Також статистично значуща різниця між цими показниками була у пацієнтів груп III та V на ранок 2-гої ( 0,016) доби, у пацієнтів груп III та IV на ранок 3-тьої (p = 0,008) доби, у пацієнтів груп IV та V на ранок 2-гої (p = 0,016) та 3-тьої $(\mathrm{p}=0,002)$ доби, у пацієнтів груп II та IV на ранок 3-тьої $(\mathrm{p}=0,008)$ доби після операції.

На вечір 1-шої доби після операції за 6 хв пацієнти групи I долали $(10,9 \pm 1,6)$ м, групи II - $(17,8 \pm 2,4)$ м, групи III - $(12,7 \pm 1,8)$ м, групи IV $-(13,1 \pm 1,6)$ м, групи V $(14,6 \pm 1,6)$ м, групи VI - $(10,6 \pm 1,3)$ м. На вечір $2-$ гої доби після операції за 6 хв пацієнти групи I проходили (44,4 $\pm 4,7)$ м, групи II - $(60,8 \pm 6,5)$ м, групи III $-(59,5 \pm 5,3)$ м, групи IV - $(51,5 \pm 4,2)$ м, групи V - $(72,4 \pm 5,7)$ м, групи VI - $(43,5 \pm 4,2)$ м. На вечір 3-тьої доби після операції пацієнти групи I змогли пройти вже $(78,7 \pm 5,2)$ м, групи II $(112,9 \pm 8,8)$ м, групи III - $(114,2 \pm 6,9)$ м, групи IV - $(86,7$ $\pm 6,8)$ м, групи V - $(113,0 \pm 7,8)$ м, групи VI - $(85,0 \pm 5,5)$ м (puc. 2). 


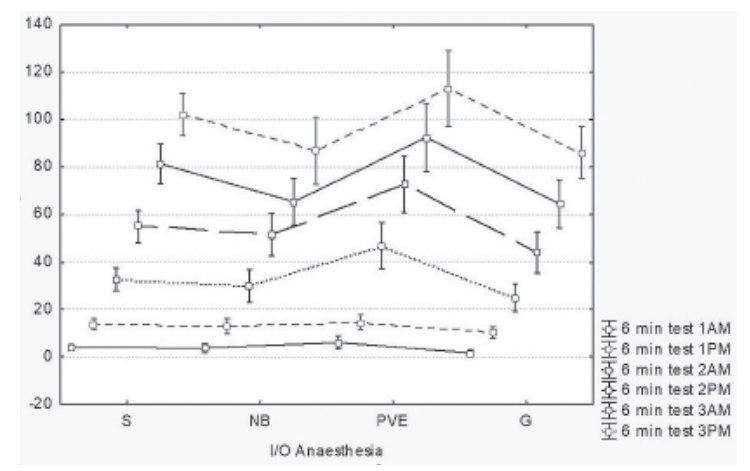

Puc. 3

Відстань, подолана пацієнтами за 6 хв, в залежності від IO анестезї̈ (S-спінальна анестезія, $N B$ - нервові блоки, PVE - паравертебральнии блок з каудальною блокадою, $G$-загальна анестезія).

Показники у групі I були статистично значно нижчі, ніж у групі II на вечір 1 -шої $(\mathrm{p}=0,021), 2$-гої $(\mathrm{p}=0,047)$ та 3-тьої ( $\mathrm{p}=0,002)$ доби після операції, ніж у групі V на вечір 2-гої $(\mathrm{p}<0,001)$ та 3-тьої $(\mathrm{p}<0,001)$ та у групі III на вечір 2-гої (p = 0,040) та 3-тьої (p < 0,001) доби після операціі. За 6 хв пацієнти групи VI проходили статистично значно меншу відстань, ніж пацієнти групи II на вечір 1-шої ( $\mathrm{p}=0,011), 2$-гої $(\mathrm{p}=0,032)$ та 3-тьої $(\mathrm{p}=$ 0,029) доби після операції, ніж пацієнти групи V на вечір 2-гої (p < 0,001) та 3-тьої $(\mathrm{p}=0,005)$ та пацієнти групи III на вечір 2-гої ( $\mathrm{p}=0,024)$ та 3-тьої $(\mathrm{p}=0,002)$ доби після операції. Також статистично значуща різниця між показниками була у групах IV та V на вечір 2-гої ( $p=0,005)$ та 3-тьої ( $\mathrm{p}=0,014)$ доби після операції, між показниками у групах IV та II (p=0,023) і групі III ( $(\mathrm{p}=0,007)$ на вечір 3-тьої доби після операції.

У пацієнтів використані чотири варіанти IO анестезіі. Результати 6-хвилинного тесту оцінювали також у залежності від варіанта IО анестезії (рис.3).

У пацієнтів, яких оперували з використанням паравертебральної блокади в поєднанні з каудальною епідуральною анестезією (n = 25), зареєстровані найкращі показники протягом перших трьох діб після операції, які статистично значущо відрізнялися у всіх шести тестах від показників у пацієнтів, яких оперували під загальною анестезією $(\mathrm{n}=25)$ : $\mathrm{p}=0,004 ; 0,04 ; 0,0002 ; 0,0002 ; 0,001$ та 0,006 відповідно; протягом 2-гої та 3-тьої доби після операції в порівнянні з показниками у пацієнтів, оперованих в умовах провідникової анестезіі $(n=25)$ : $\mathrm{p}=0,005$; 0,005; 0,002 та 0,01 відповідно; протягом 2-гої доби після операції в порівнянні з показниками у пацієнтів, оперованих під спінальною анестезією $(\mathrm{n}=75)$ : $\mathrm{p}=0,005$ та 0,009 відповідно. Пацієнти, яких оперували в умовах спінальної анестезії, показали кращий результат у порівнянні з пацієнтами, яких оперували під загальною анестезією, на ранок 1 -шої доби після операції $(\mathrm{p}=0,049)$ та в порівнянні з пацієнтами, яких оперували в умовах блокади нервів, на ранок $(\mathrm{p}=0,04)$ 3-тьої доби після операції.

У пацієнтів використані три варіанти ПО аналгезіі. Результати 6-хвилинного тесту оцінені в залежності від варіанта ПО аналгезії (рис. 4).

Пацієнти, у яких використовували паравертебральну аналгезію (n = 50), значно краще долали відстань за 6 хв

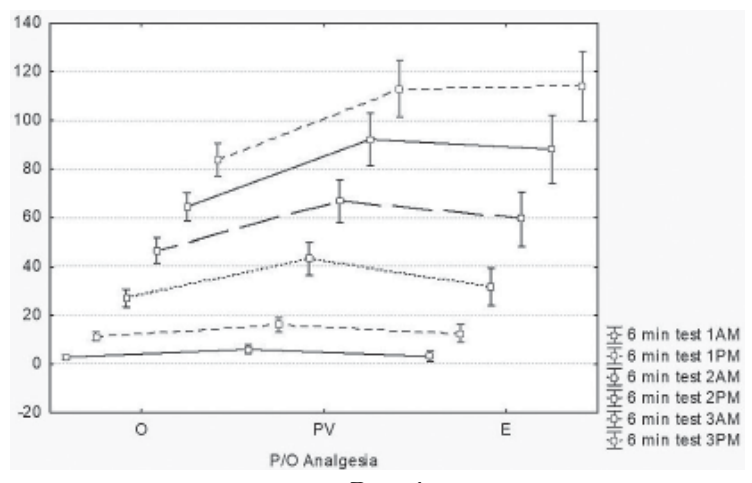

Puc. 4.

Відстань, подолана пацієнтами за 6 хв, в залежності від способу знеболювання після операщії (O - опіоїди, PV - паравертебральна аналгезія, E-епідуральна аналгезія).

у порівнянні з пацієнтами, яким застосовували системне введення опіоїдів ( $\mathrm{n}=75)$ (різниця між показниками статистично значуща у всіх шести тестах: $\mathrm{p}=0,0007 ; 0,003$; 0,00001; 0,00004; 0,000003, 0,000008 відповідно), та навіть у порівнянні з пацієнтами, які отримували тривалу епідуральну аналгезію ( $\mathrm{n}=25)$, на ранок 2-гої доби після операції ( $\mathrm{p}=0,04)$. Результати у пацієнтів, які отримували епідуральну аналгезію, істотно відрізнялися від результатів у пацієнтів, яким застосовували системне введення опіоїдів, на вечір 2-гої та на 3-тю добу після операції ( $=0,02 ; 0,0003 ; 0,00004$ відповідно).

\section{Обговорення}

У пацієнтів, яких оперують з приводу ендопротезування КС, застосовують як різні варіанти анестезії під час самої операції, так і різні програми знеболювання після оперативного втручання [5]. Рання мобілізація є одним 3 пріоритетів після повної заміни КС. Фізичну активність у ранньому післяопераційному періоді обмежує здебільшого біль, тому пацієнтам потрібна адекватна аналгезія без седативного ефекту та м'язової слабості в нижніх кінцівках. Сучасні протоколи знеболювання після повної артропластики містять рекомендації обмежувати використання опіоїдів та віддавати перевагу периферичним нервовим блокам [2]. Однак потреба в опіоїдах значно вище після загальної анестезії, ніж після регіонарної чи комбінованої [3].

Нейраксіальні методи (спінальна та епідуральна анестезія) забезпечують адекватну блокаду больових імпульсів на рівні спинного мозку та його корінців. Але супутні проблеми (м'язова слабість в ногах та гемодинамічна нестабільність під час епідуральної аналгезіі), погіршуючи загальний стан пацієнтів, можуть впливати на їх відновлення [4]. Паравертебральні блоки діють безпосередньо на спинномозкові нерви відразу після виходу іх 3 міжхребцевого отвору. Цей метод забезпечує адекватну аналгезію з симпатичною блокадою та стабільними гемодинамічними параметрами. Потужність моторного блоку за допомогою паравертебральної аналгезії можна регулювати зміною концентрації місцевого анестетика [6].

Ми застосували різні варіанти ІО анестезії та ПО аналгезіі. Отримані результати показали, що фізична активність пацієнтів більше залежить від ПО аналгезії, ніж від 
методу IO анестезіі. Шляхом визначення відстані, яку подолали пацієнти за 6 хв в перші доби після операції, ми виявили перевагу пролонгованих паравертебральних блоків у порівнянні з системним введенням опіоїдів після загальної або спінальної анестезії. Виявлене нами більш повільне відновлення здатності рухатися у пацієнтів, яких знеболювали опіоїдами в післяопераційному періоді, можна пояснити залишковим седативним ефектом цих препаратів, що знижувало загальну активність пацієнтів. Окрім цього, багато інших побічних ефектів (нудота та блювання, затримка сечі, запаморочення) також можуть погіршувати загальний стан пацієнтів. Ефект мультимодального управління болем під час відновлення після ендопротезування КС вивчали F. J. Singelyn і співавтори [7], які порівнювали ефекти трьох режимів контролю болю (внутрішньовенне контрольоване аналгезією (ПСА) $з$ морфіном, тривале епідуральне знеболювання та тривале блокування стегнового нерва) і дійшли висновку про подібне зменшення болю всіма трьома способами, але віддали перевагу пролонгованому блоку стегнового нерва через меншу кількість системних побічних ефектів. Ми відмовилися від блокади стегнового нерва під паховою складкою, яка виконується практично на рівні оперативного втручання, тому іï аналгетичний ефект пов'язаний не стільки з блокадою передачі болю з місця операції, скільки з релаксацією чотириголового м'яза стегна, що загрожує ймовірним падінням хворого навіть у разі використання місцевих анестетиків низької концентрації. Тому більш доцільно під час хірургічних втручань на КС блокувати поперекову групу нервів (стегновий, затульний та зовнішній шкірний нерви стегна) разом заднім доступом на поперековому рівні. Моторний компонент цих нервових блоків легко контролюється концентрацією та об'ємом місцевого анестетика.

C. Вессhі і співавтори [8] продемонстрували перевагу псоас-компартмент блоку у порівнянні з опіоїдними/ нестероїдними протизапальними препаратами у вигляді безперервної внутрішньовенної інфузії у хворих після ендопротезування КС, виконаного в умовах спінальної анестезії. Пацієнти, які отримували безперервний псоас-компартмент блок, мали краще знеболення у стані спокою та після мобілізації, не страждали від нудоти, блювання та порушень гемодинаміки.

\section{Висновки}

1. Методики з пролонгованим регіонарним знеболюванням (епідуральним або паравертебральним) забезпечували кращі умови для фізичного відновлення пацієнтів у порівнянні з будь-якою ізольованою методикою (загальна, спінальна анестезія, блокади нервів) при артропластиці КС.

2. Результати оцінювання відстаней, які пацієнти могли долати за 6 хв, продемонстрували пріоритетність паравертебральних блоків у порівнянні з системним призначенням опіоїдів.

3. Паравертебральний блок сприяє ранньому фізичному відновленню пацієнтів після артропластики КС.

\section{References}

1. Ranawat AS, Ranawat CS. Pain management and accelerated rehabilitation for total hip and total knee arthroplasty. J Arthroplasty. 2007 Oct;22(7 Suppl 3):12-5. doi: 10.1016/j.arth.2007.05.040. PMID: 17919586.

2. Horlocker TT, Kopp SL, Pagnano MW, Hebl JR. Analgesia for total hip and knee arthroplasty: a multimodal pathway featuring peripheral nerve block. J Am Acad Orthop Surg. 2006 Mar;14(3):126-35. PMID: 16520363.

3. Greimel F, Maderbacher G, Zeman F, Grifka J, Meissner W, Benditz A. No Clinical Difference Comparing General, Regional, and Combination Anesthesia in Hip Arthroplasty: A Multicenter CohortStudy Regarding Perioperative Pain Management and Patient Satisfaction. J Arthroplasty. 2017 Nov;32(11):3429-3433. doi: 10.1016/j. arth.2017.05.038. Epub 2017 May 26.

4. Johnson RL, Kopp SL, Burkle CM, Duncan CM, Jacob AK, Erwin PJ, et al. Neuraxial vs general anaesthesia for total hip and total knee arthroplasty: a systematic review of comparative-effectiveness research. Br J Anaesth. 2016 Feb;116(2):163-76. doi: 10.1093/bja/aev455.

5. Shan L, Shan B, Graham D, Saxena A. Total hip replacement: a systematic review and meta-analysis on mid-term quality of life. Osteoarthritis Cartilage. 2014;22:389-406. doi: 10.1016/j.joca.2013.12.006.

6. Demirel I, Ozer AB, Duzgol O, Bayar MK, Karakurt L, Erhan OL. Comparison of unilateral spinal anesthesia and LI paravertebral block combined with psoas compartment and sciatic nerve block in patients to undergo partial hip prosthesis. Eur Rev Med Pharmacol Sci. 2014;18(7):1067-72.

7. Singelyn FJ, Ferrant T, Malisse MF, Joris D. Effects of intravenous patient-controlled analgesia with morphine, continuous epidural analgesia, and continuous femoral nerve sheath block on rehabilitation after unilateral total hip arthroplasty. Reg Anesth Pain Med. 2005;30(5):4527. doi: 10.1016/j.rapm.2005.05.008. PMID: 16135349.

8. Becchi C, Al Malyan M, Coppini R, Campolo M, Magherini M, Boncinelli S. Opioid-free analgesia by continuous psoas compartment block after total hip arthroplasty. A randomized study. Eur J Anaesthesiol. 2008 May;25(5):418-23. Epub 2007 Nov 21. doi: 10.1017/ S026502150700302X. PMID: 18028577. 